University of Nebraska - Lincoln

DigitalCommons@University of Nebraska - Lincoln

Textile Society of America Symposium

Proceedings

Textile Society of America

2020

\title{
Tribal Textiles and the Mingei Circle in Japan: Muneyoshi Yanagi's View on Carpet
}

Yumiko Kamada

Follow this and additional works at: https://digitalcommons.unl.edu/tsaconf

Part of the Art and Materials Conservation Commons, Art Practice Commons, Fashion Design Commons, Fiber, Textile, and Weaving Arts Commons, Fine Arts Commons, and the Museum Studies Commons

This Article is brought to you for free and open access by the Textile Society of America at DigitalCommons@University of Nebraska - Lincoln. It has been accepted for inclusion in Textile Society of America Symposium Proceedings by an authorized administrator of DigitalCommons@University of Nebraska - Lincoln. 


\title{
Tribal Textiles and the Mingei Circle in Japan: Muneyoshi Yanagi's View on Carpet
}

\author{
Yumiko Kamada \\ kamada.a6@keio.jp
}

\section{Introduction}

Tribal carpets and textiles have been enthusiastically collected by connoisseurs and others in Europe and the United States for years. Along with a number of publications on tribal carpets and textiles, several recent exhibitions such as Portable Storage: Tribal Weavings from the Collection of William and Inger Ginsberg at the Metropolitan Museum of Art in 2017-2018 indicate a keen academic interest in the West. In contrast, tribal carpets and textiles have not gained much attention among the majority of Japanese. However, some Japanese, especially Muneyoshi Yanagi and his friends in the Mingei circle, notably Shoji Hamada, Keisuke Serizawa, and Kichinosuke Tonomura, have collected tribal carpets and textiles since the mid-twentieth century. This paper focuses on this little-known fact and explores how and in what circumstances these textiles were collected. In addition, this paper examines why carpets and tribal textiles were highly valued by the Mingei circle and compares their view with William Morris's attitude toward Oriental carpets. ${ }^{1}$

\section{Interest in tribal carpet in Europe and America}

From the 1870s onward, carpets from Iran, Turkey, Central Asia, and India were collected by European museums as a subject of study and as a source of design for the applied arts.

Alongside this interest in Oriental carpets, there were frequent exhibitions and publications on carpets. Initially, Persian carpets were viewed as the most valuable. However, from the end of the nineteenth century to the early twentieth century, some people started to collect tribal carpets for the purpose of interior embellishment. For instance, Swedish aristocrat Wilhelmina von Hallwyl (1844-1930) purchased Turkmen bags in Berlin and used them as textiles for soft furnishings (Fig. 1). ${ }^{2}$ Similarly, a Scottish businessman William Robert Reid (1854-1919) used a Turkmen tent band for the curtain rails in the castle he purchased in 1902. ${ }^{3}$ Not only Europeans, but also Americans collected tribal carpets. James Franklin Ballard (1851-1931) collected a variety of carpets, including Turkmen carpets that were not that popular in the United States at the beginning of the twentieth century. ${ }^{4}$

\footnotetext{
1 Part of this paper is based on Yumiko Kamada, "Yanagi Muneyoshi no Shizenkan to Jutan (Yanagi Muneyoshi's view on nature and carpet)" in Kanzaki, Tadaaki and Nomoto, Shin eds., Shizen o mae ni shita Ningen no Tetsugaku (Philosophy of human being that faces nature), Tokyo: Keio University Press, 2020, 241267.

2 Cassel-Phil Eva Helena, Jennifer Wearden, and Anette Granlund, The Hallwyl Collection of Oriental Carpets and Textiles, (Stockholm: Hallwylska Museet, 2003).

3 Eastern Rugs from Lauriston, (Edinburgh: Edinburgh City Museum and Art Galleries, 1986).

4 Walter B. Denny, and Thomas J. Farnham, The Carpet and the Connoisseur: The James F. Ballard Collection of Oriental Rugs, (St. Louis: Saint Louis Art Museum, 2016).
} 


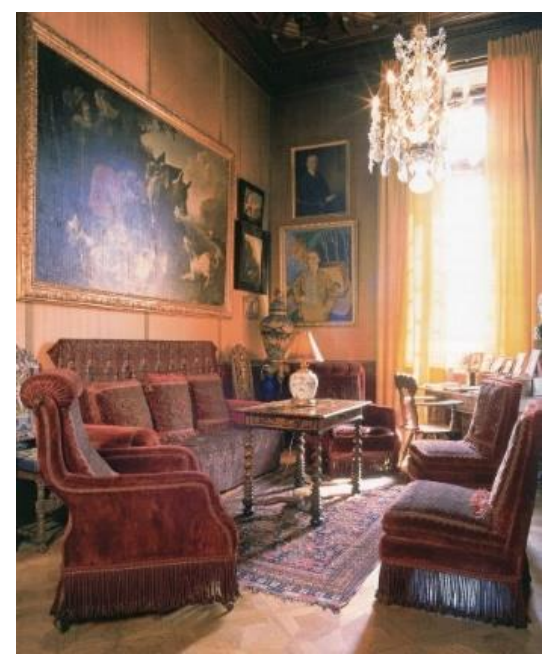

Fig. 1 Residence of Wilhelmina von Hallwyl (1844-1930) using Turkmen carpets as soft furnishings

After Cassel-Pihl, The Hallwyl Collection, 62

In the early twentieth century, several handy guidebooks on carpets were published in which tribal carpets were also introduced. Among these publications are Hawley's Oriental Rugs: Antique and Modern (1913), Kendrick and Tattersall's Hand-Woven Carpets (1922), and Mumford's Oriental Rugs (1929). As indicated in a plate in Jacobson's Facts about Oriental Rugs (1931) that shows a Bakhtiari pillow being used as a cover for a chair, this kind of guidebook illustrated how to use tribal carpets as a part of the interior. This fashion is also evident in a photograph of a New York businessman Arthur Arwine taken around 1930, ${ }^{5}$ which shows one way in which ardent collectors used tribal carpets to decorate their homes.

\section{Japanese interest in Oriental Carpet}

As discussed elsewhere by the author, Indian and Persian carpets were brought to Edo-period Japan by the Dutch East India Company and used for special occasions such as the Kyoto Gion festival. ${ }^{6}$ Catalogues of art auctions held in Kyoto, Osaka, and Tokyo at the beginning of the twentieth century indicate that several prominent figures and wealthy merchants owned eighteenth-to-nineteenth-century Indian carpets from the Edo period onward. However, while Japanese people were gradually exposed to the use of carpet because of a westernization process that occurred after the Meiji period (1868-1912), very few had the opportunity to see Oriental carpets firsthand.

\footnotetext{
5 For the photograph, see Jon Thompson, Timbuktu to Tibet: Exotic Rugs \& Textiles from New Collectors, (New York: The Hajji Baba Club, 2008), 21.

6 Yumiko Kamada, Flowers on Floats: The Production, Circulation, and Reception of Early Modern Indian Carpets. Ph.D. Dissertation, Institute of Fines Arts, New York University, 2011; Yumiko Kamada, Jutan ga musubu sekai. (Nagoya: The University of Nagoya Press, 2016).
} 
From the early twentieth century, only a privileged few, such as aristocrats, scholars, and businessmen, had the chance to visit Europe and the United States and become exposed to carpets as everyday furnishings. For instance, as shown in a photograph taken in 1914, a famous Japanese novelist Soseki Natsume (1867-1916) cherished a large Oriental carpet and used it in his library (Fig. 2). Probably, this is because Soseki learned how Europeans used Oriental carpets as interior decoration during his stay in England in 1900-1902. Similarly, a wealthy businessman Shotaro Kaga (加賀正太郎1888-1954) traveled around Europe in 1910 and went on to build an English-style mountain villa in Oyamazaki (大山崎) in Kyoto Prefecture that was completed in around 1932. He embellished the villa with Oriental carpets, one of which appears to be a Qashqai kilim made by nomads in Iran (Fig. 3). ${ }^{7}$

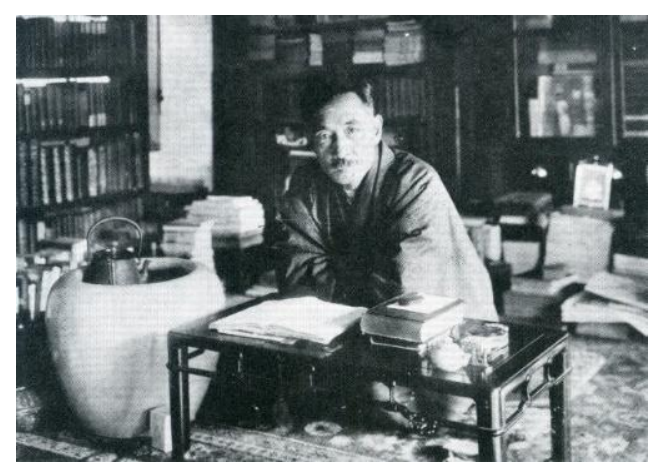

Fig. 2 Soseki Natsume in his library furnished with Oriental carpet, 1914 After Matsuoka, Soseki Shashinjyo

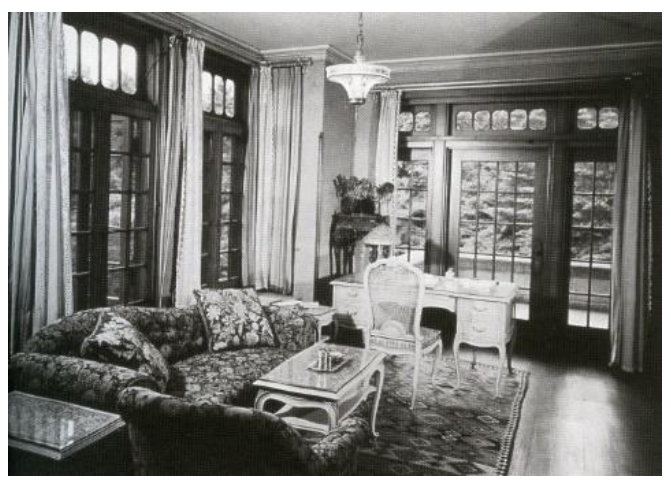

Fig. 3 Residence of businessman Shotaro Kaga (1888-1954) with kilim After Asahi Beer, Oyamazaki Sanso Bijutsukan Guidebook, 11

Moritatsu Hosokawa (細/碓立1883-1970), who was born into a noble family of Marquis rank also used Oriental carpet at home. In addition to his visit to the United States in 1906, Hosokawa had the chance to travel around Europe in 1826-1828 during which time he

\footnotetext{
7 For more detail on Shotaro Kaga's villa, see Asahi Beer Oyamazaki Villa Museum of Art, Oyamazaki Sanso Bijutsukan Guidebook, (2012), 8-11.
} 
viewed and studied various artworks, especially Middle Eastern art such as Persian paintings and pottery. ${ }^{8}$ Hosokawa especially valued Islamic textiles, writing:

Persian textiles exemplified how high the standard of Persian culture was. It goes without saying that textiles from Turkey, Central Asia, and Iran are now highly valued and collected by museums and private collectors in Europe and in the United States. I learnt this fact before my travel to Europe and therefore I viewed such textiles in European collections with great expectations. ${ }^{9}$

Hosokawa purchased several carpets and textiles woven in Iran and Central Asia during his stay in Europe. After his return, Hosokawa had the chance to show part of his collection to the wider public because, in 1928, his collection of Persian pottery, Persian textiles, kilims and Turkmen bags were exhibited upon the tenth anniversary of the Keimeikai Foundation (Fig. 4). With regard to this exhibition, he wrote: "My collection caused a great sensation and probably this was because Japanese have not had sufficient opportunities to see such things until now." $" 10$

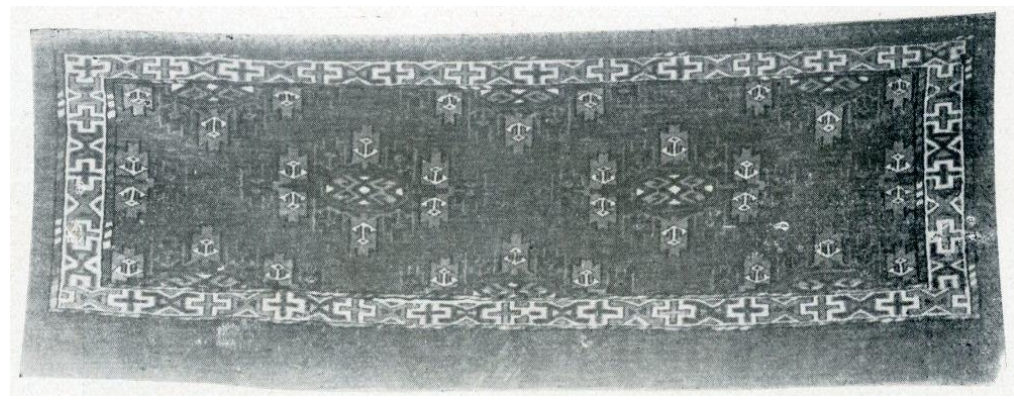

Fig. 4 One of the tribal carpets collected by Moritatsu Hosokawa After Keimeikai, Keimeikai Soritsu Junen Kinen Tenrankai Zuroku, 132.

As exemplified by another businessman Kojiro Kawamura (河村幸次郎 1901-1994), who traveled in the United States and Europe in 1928 and purchased Persian carpet(s), Syrian textile(s), Turkish chintz and Egyptian embroidery, ${ }^{11}$ it seems that by the 1920 s, a small number of people who had the privilege and means to travel to Europe and America were able to acquire Oriental carpets.

From the 1920s onward, several books on carpets were published. For instance, Chua Geijutsu Shusei (中覀㙯術集成Collection of the Arts of Central Asia) published in 1924 by the Association of Designers shows kilims and bags made by nomads. ${ }^{12}$ Also, the 1928

\footnotetext{
8 Morihiro Hosokawa, ed., Bi ni ikita Hosokawa Moritatsu no Me, (Tokyo: Kyuryudo, 2010), 191-195, 228229.

9 Hosokawa, 196.

${ }^{10}$ Hosokawa, 198.

11 Shimonoseki City Art Museum, Kawamura Kojiro to Bi no Sekai, (2013), 17, 98.

12 Zuanka Kyokai, Chua Geijutsu Shusei, (Kyoto, 1924), pls. 25 and 26.
} 
catalogue of the above-mentioned exhibition for the tenth anniversary of the Keimeikai Foundation also includes several images of Oriental carpets. ${ }^{13}$ Besides, some guidebooks explain how to use Oriental carpet as interior decoration. For instance, in his book on interior decoration published in 1927, Nobuo Moriya (森谷延雄 893-1927) illustrates how to use Turkish, Persian, Indian, and European carpet as home décor. ${ }^{14}$ Similarly, in the section on floorspreads in a 1938 book on interior design, the author Shinpei Masuyama (増山新何) introduces Turkish, Persian, Indian and Chinese hand-woven carpets as the most artistic types of floorspreads (Fig. 5). ${ }^{15}$
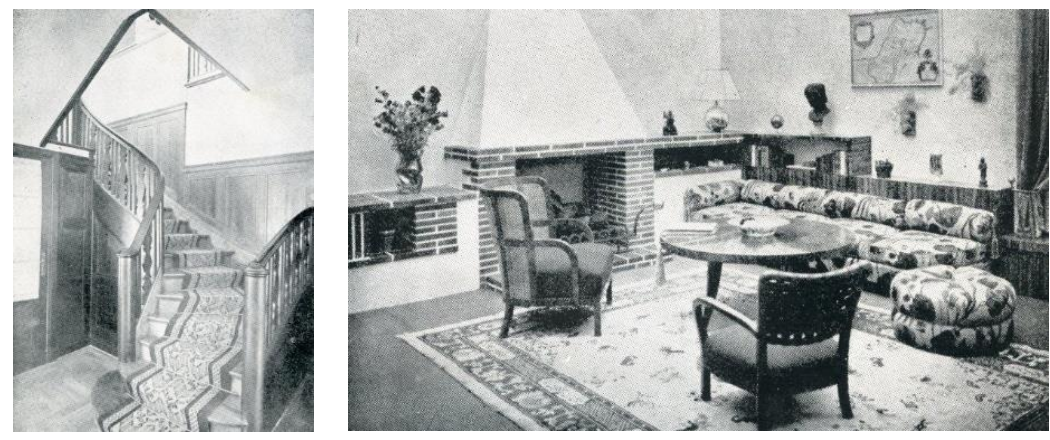

Fig. 5 Shinpei Masuyama's book on interior design

After Masuyama, Shinjidai no Shitsunai Setsubi Kozo Zukai

\section{Muneyoshi Yanagi's view on carpet}

Yanagi's life

While several Japanese handbooks on the use of carpet as interior decoration were published in the 1920s, most Japanese were unfamiliar with carpets at that time. It was in this context that Muneyoshi Yanagi (柳宗悦1889-1961) found beauty in carpet designs and came to regard carpets and tribal textiles as idealized artifacts.

Yanagi was born in 1889 and after graduating from the University of Tokyo in 1913 he pursued his thought on art and religious philosophy. From the mid-1920s, he named artifacts made by anonymous craftsmen as "Mingei" and promoted the Mingei Movement with potters Kanjiro Kawai (河井寛次郎) and Shoji Hamada (濱田庄司). In 1929-1930, after he had visited England and other countries in Europe, Yanagi went to the United States to work as a lecturer at Harvard University. After his return to Japan, he published a journal entitled Kogei (工藝) in 1931, and established the Japan Folk Crafts Museum (Nihon Mingeikan) in Tokyo in 1936. Throughout his lifetime, Yanagi traveled not only to various places in Japan, but also extensively in Asia, Europe, and the United States. During his travels, he collected a variety of artifacts that he later exhibited. In 1952-1953 on trips to Europe and the United States to

13 Keimeikai, Keimeikai Soritsu Junen Kinen Tenrankai Zuroku, (Tokyo, 1928), 130-133.

14 Nobuo Moriya, Korekara no Shitsunai Soshoku, (Tokyo, 1927).

15 Shinpei, Masuyama, Shinjidai no Shitsunai Setsubi Kozo Zukai, (Tokyo, 1938), 106-108. 
give lectures, he collected several artifacts that he then exhibited in the Japan Folk Crafts Museum. Until his death in 1961, he was energetically engaged in conducting research, collecting, and writing.

Yanagi's view on carpet

In a 1942 article entitled "The teaching of artifacts," Yanagi states that "nature" and "history" are the necessary elements for great artifacts. In that article he explains that "nature" includes climates, geographical change, and types of material, while "history" includes changes in lifestyles, customs, and manners, and the continuation of knowledge and techniques. ${ }^{16}$ At the same time, Yanagi uses "nature" to mean "without contrivance." Interestingly, in his 1939 article on print art, Yanagi refers to carpet as an artifact that follows the principle of "nature" and that therefore embodies superior design. He explains that because of the material and the simple weave structure of carpet, it is often difficult to make curvilinear lines, yet it is this limitation caused by the material and the process of weaving that contributes to the beauty of carpets. ${ }^{17}$ In other words, working within such limitations, or, following "nature" is a prerequisite for the making of beautiful artifacts.

Similarly, in a 1942 article on design, Yanagi states that while a design is produced by a human being's technique, design should apply the principle of "nature." According to Yanagi, the limitations caused by purpose, material, and technique are indispensable in good design. Indeed, he acclaims carpets because of the design limitation imposed by the weaving methods. $^{18}$

Tribal bag in Yanagi's library

In the 1950s, Yanagi used a woven carpet bag (khorjin) made by a Persian nomad as a cushion in his library (Fig. 6). At that time, it was difficult to obtain such tribal goods in Japan and it seems that Yanagi purchased the bag at some point during his travels in Europe and the United States in 1952-1953. His reason for purchasing this bag may well have been because tribal carpets possess all the characteristics that Yanagi advocated for in relation to artifacts. In a 1941 article entitled "The characteristics of the beauty of artifacts," he employs the following words to describe the characteristics of artifacts: "practical," "repetitive (i.e., producing same objects in large number)," "inexpensive," "public," "canonical (based on a traditional method)," “design," "anonymous," "indirect (far from contrivance)," and "not flexible (i.e., constrained by purpose, material and process)" ${ }^{19}$

\footnotetext{
16 Nihon Mingeikan ed., Yanagi Muneyoshi Zenshu, vol. 10, 1982, 506.

17 Nihon Mingeikan ed., Yanagi Muneyoshi Collection, vol. 2, 2011, 172.

18 Nihon Mingeikan ed., Yanagi Muneyoshi Collection, vol. 2, 2011, 235-236.

19 Muneyoshi Yanagi, Yanagi Muneyoshi Senshu, vol. 3, Tokyo, 1954, 226-287.
} 
Generally in nomadic cultures, tribal carpets are woven by the female members of a family and they are decorated with traditional designs. These anonymous tribal carpets are woven to fit the daily life of the nomad and are therefore both practical and simple. When Yanagi came across such a woven bag, given his view on design, he must have regarded it as an ideal artifact. If Yanagi had lived in the current era, it is very likely that he would have been an eminent collector of tribal carpets and textiles. However, because of limited accessibility to such objects in Japan during his lifetime, Yanagi owned just a few tribal textiles.

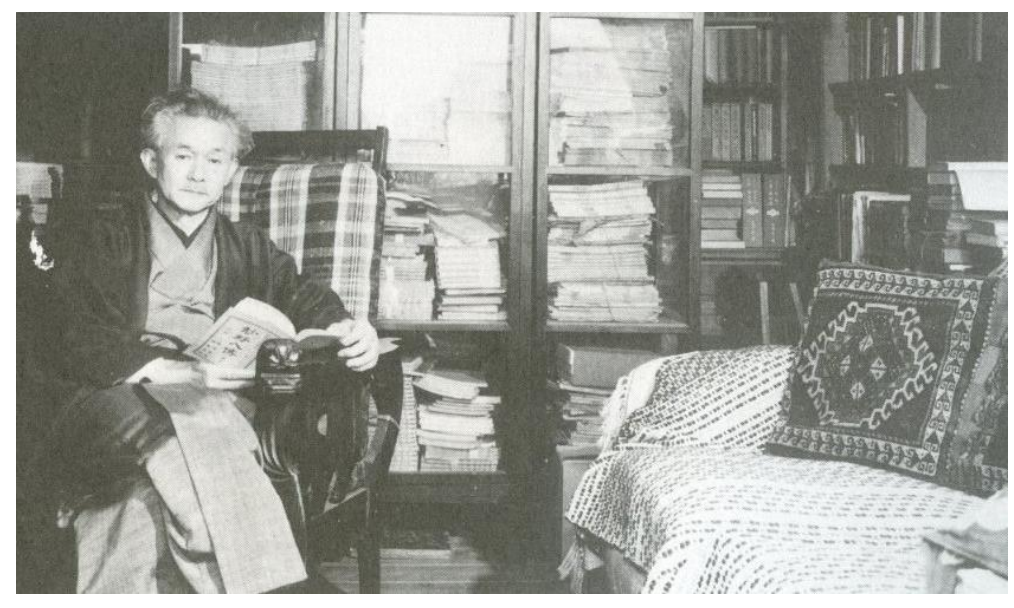

Fig. 6 Yanagi Muneyoshi in his library

After Mie Prefectural Museum, Yanagi Muneyoshi Ten, 216

In Japan, Yanagi was a pioneer in praising the beauty of the textiles woven by nomads, indigenous Taiwanese, and the peoples of Africa. At the same time, he asked textile weavers of the day to reflect on their works. For instance, in 1943, he praised the textiles woven by the indigenous people of Taiwan, stating that they were as sophisticated as those in Shosoin (imperial treasure house in Nara, Japan) and that the best contemporary weavers could not produce textiles of comparable quality. ${ }^{20}$

\section{Similarity with William Morris}

Yanagi's abovementioned views on artifacts and carpets remind us of the attitude of William Morris (1834-1896) toward art and carpet. Morris was active as a designer, thinker, and social activist and tried to bring about a resurgence of "the art of the people" that had flourished in the Middle Ages. Morris's works were introduced to Japan from the mid-Meiji period onward and in this regard Yanagi wrote that "thanks to John Ruskin and William Morris, the field of craft was raised to become an important subject of beauty", and in 1929 Yanagi visited Kelmscott House, the London home of Morris from 1878 till his death. ${ }^{21}$

\footnotetext{
${ }^{20}$ Hiroshi Mizuo, ed., Yanagi Muneyoshi Mingei Kiko, (Tokyo, 1995), 282.

21 MuneyoshiYanagi, Watashi no Nengan, (Tokyo, 1942), 28-37, esp. 35.
} 
Morris also attached importance to nature, writing, "For, and this is at the root of the whole matter, everything made by man's hands has a form, which must be either beautiful or ugly; beautiful if it is in accord with Nature, and helps her; ugly if it is discordant with Nature, and thwarts her; it cannot be indifferent." 22 On another occasion, he states: "Men could do no otherwise when they built than give some gift of beauty to the world: but all is turned inside out now, and when men build they cannot but take away some gift of beauty, which Nature or their own forefathers have given to the World."23

Furthermore, Morris's thought on materials and their limitations is comparable to that expressed in Yanagi's abovementioned observation on design, as exemplified by the following extract from Morris's writings:

As final maxims: never forget the material you are working with, and try always to use it for doing what it can do best: if you feel yourself hampered by the material in which you are working, instead of being helped by it, you have so far not learned your business, any more than a would-be poet has, who complains of the hardship of writing in measure and rhyme. The special limitations of the material should be a pleasure to you, not a hindrance: a designer, therefore, should always thoroughly understand the processes of the special manufacture he is dealing with, or the result will be a mere tour de force. On the other hand, it is the pleasure in understanding the capabilities of a special material, and using them for suggesting (not imitating) natural beauty and incident, that gives the raison d'être of decorative art. ${ }^{24}$

Morris also had strong interest in Oriental carpets, using Persian carpets in the so-called Red House where he lived from $1860 .^{25}$ Also, in a letter to his daughter May in 1876, he reported his recent purchase of a Persian carpet. ${ }^{26}$ On another occasion in 1877 , he writes: "I saw yesterday a piece of ancient Persian, time of Shah Abbas that fairly threw me on my back: I had no idea that such wonders could be done in carpets..."27 In fact, as with Yanagi, Morris used Persian carpet in his daily life. For instance, the wall of the dining room at Kelmscott House was beautifully decorated with a seventeenth-century Persian carpet (Fig. 7). ${ }^{28}$

\footnotetext{
22 William Morris, The Collected Works of William Morris, vol. 22, (London, 1914), 4.

23 Morris, 130-131.

24 May Morris, William Morris: Artist, Writer, Socialist, vol. 1, (New York, 1966), 251.

25 Paul Richard Thompson, The Work of William Morris, (New York: The Viking Press, 1967), 68.

26 Parry, Linda, William Morris Textiles, New York, 1983, 85.

27 Philip Henderson, ed., The Letters of William Morris to His Family and Friends, (London: Longmans, 1950), 90.

28 This carpet is currently preserved in the Victoria and Albert Museum (719-1897).
} 


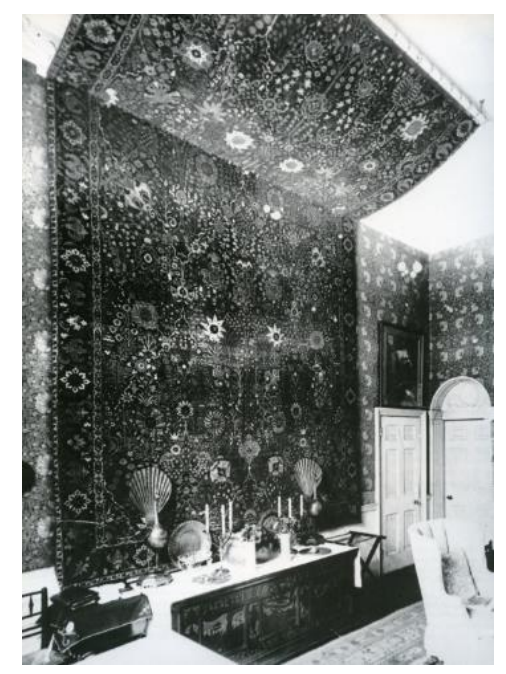

Fig. 7 Seventeenth-century Persian carpet on the wall of the dining room of Kelmscott House, 1890s.

William Morris Gallery, London Borough of Waltham Forest

At the same time, Oriental carpets inspired Morris's work as a designer. From 1879, Morris himself weaved the so-called "Hammersmith carpet" while residing at Kelmscott House and this carpet is clearly influenced by both Persian and Indian carpets. ${ }^{29}$ It is likely that he had the opportunity to closely examine Persian carpets and other artifacts in the South Kensington Museum with which he had strong relationship since the $1860 \mathrm{~s} .{ }^{30}$ Also, as is well known, in 1893, Morris encouraged the Victoria and Albert Museum to purchase the famous Ardabil carpet.

In his thought, Morris describes the characteristics of what constituted "good" work as "hope", describing hope as follows:

Hope of rest, hope of product, hope of pleasure in the work itself; and hope of these also in some abundance and of good quality; rest enough and good enough to be worth having; product worth having by one who is neither a fool nor an ascetic; pleasure enough for all for us to be conscious of it while we are at work; not a mere habit, the loss of which we shall feel as a fidgety man feels the loss of the bit of string he fidgets with. $^{31}$

It seems that Morris viewed Persian and Indian carpets as examples of "good" work and that they should therefore be protected from the machine age. Hence, he could not bear the thought that the tradition of producing hand-woven carpet was declining because of modernization. In fact, in 1879 he delivered a speech at the Birmingham Society of Arts in

\footnotetext{
29 Philip Henderson, William Morris: His Life, Work and Friends, (London: Thames \& Hudson, 1967), 154.

30 Barbara Morris, "William Morris and the South Kensington Museum," Victorian Poetry 13 (1975), 159-175, esp. 160-161.

31 William Morris, Collected Works of William Morris, vol. 23, (London, 1915), 99.
} 
which he mentioned that traditional Indian handicrafts including carpet had been destroyed by the British and modern trading. ${ }^{32}$ Additionally, Morris highly valued handicrafts by Kurdish nomads as he states: "I am most sure that all the heaped-up knowledge of modern science, all the energy of modern commerce, all the depth and spirituality of modern thought, cannot reproduce so much as the handiwork of an ignorant, superstitious Berkshire peasant of the fourteenth century; nay, of a wandering Kurdish shepherd, or of a skin-and-bone oppressed Indian ryot." 33

\section{The collecting of carpets by Yanagi's circle}

As we have seen, both Yanagi and Morris highly valued Oriental carpets and used them in their daily life. For them, such carpets and other objects made by nomads were idealized artifacts. However, in Japan, it was difficult to obtain carpets, especially tribal carpets. Therefore, in 1964, when Yanagi’s son Munemoto Yanagi (柳宗玄1917-2019) accidentally came across some bags (heybe) woven by nomads during his research on Byzantine mural paintings in Turkey, he became fascinated by their beauty ${ }^{34}$ and introduced this type of nomadic textile in the journal Mingei (Fig. 8) and in his works.
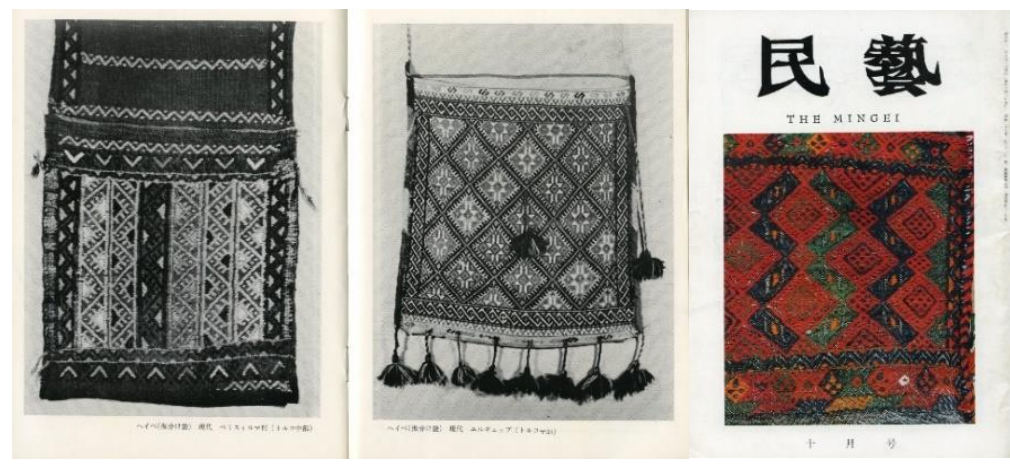

Fig. 8 Bags owned by Munemoto Yanagi

After illustrations in Mingei (178) 1967, 30-31

After World War II, Oriental carpets including tribal carpets were collected by Keisuke Serizawa (芹沢銈介1895-1984), Shoji Hamada (濱田庄司1894-1978), and Kichinosuke Tonomura (外村吉之介1898-1993) who were close to Yanagi and promoted the Mingei Movement. Whenever they had the chance to travel abroad, they purchased foreign artifacts and introduced them to Japanese audiences through exhibitions and publications.

Keisuke Serizawa (1895-1984) was a world-famous textile designer. He started his career as an industrial designer and after he met Yanagi in 1927, Serizawa became heavily involved

32 William Morris, The Art of the People, (Worcestershire, 2012), 15.

33 William Morris, The Collected Works of William Morris, vol. 22, (London, 1914), 180.

34 Munemoto Yanagi, Cappadocia no Natsu, (Tokyo, 1988), 201-217. 
with the Mingei Movement along with Hamada. Interestingly, following Yanagi's suggestion, Serizawa provided instructions for the design of Kurashiki carpets. ${ }^{35}$ In his later years, whenever Serizawa had the opportunity to go abroad, he purchased artifacts and textiles and became an extensive collector. ${ }^{36}$ His acquisitions included carpets, bags, and textiles made by nomads in Iran, Turkey, Caucasus, and Afghanistan. Serizawa not only received inspiration from these textiles but also enjoyed them as interior decoration. From the 1970s, his collection was introduced to the public through exhibitions and publications.

Today, his collection is preserved in the Shizuoka City Serizawa Keisuke Art Museum (Fig. 9) and the Tohoku Fukushi University Serizawa Keisuke Art and Craft Museum.

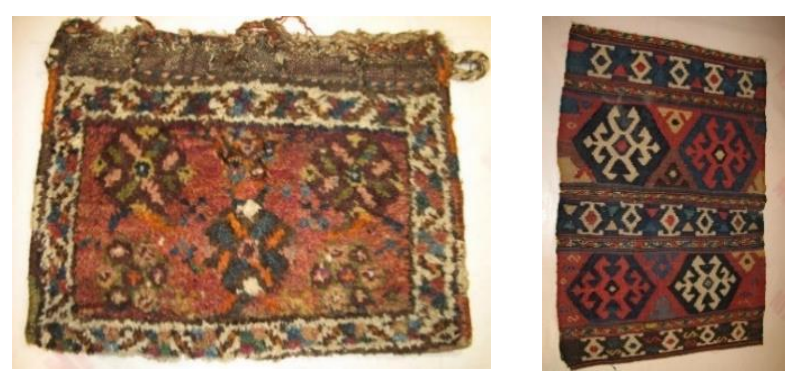

Fig. 9 Tribal textiles collected by Serizawa Keisuke in Shizuoka City Serizawa Keisuke Art Museum Photograph taken by the author

Shoji Hamada (1894-1978) was a world-famous potter and was a close friend of both Yanagi and Serizawa. As early as 1920, he went to England to study pottery and then visited Egypt on his way home to Japan in 1924. In 1929, Hamada returned to England, this time with Yanagi, to hold an exhibition in London and also traveled around Europe to collect a variety of artifacts and handicrafts. ${ }^{37}$ His experiences of traveling abroad opened his eyes to foreign cultures and art forms, including Islamic art. For instance, in 1952, he stayed in Europe and the United States and reported that the design of Hispano-Moresque pottery was the best among the European pottery styles. ${ }^{38}$ Then, in 1964, while staying in Tehran he wrote to his friend in Japan using a photographic postcard depicting Iranian nomads. ${ }^{39}$ The following year, in a 1965 article entitled, "Travel in search of foreign handicrafts," he praised the Islamic pottery in the Islamic Art Museum, Cairo. ${ }^{40}$ Hamada collected various artifacts, including textiles from Iran, Turkey, Central Asia, India, Africa, South America, and Taiwan (Fig. 10). He stated that "the reason why I collected what I liked is because these are the food

\footnotetext{
35 Akira Kanemitsu, Mingei to Kurashiki, (Okayama, 2002), 127, 129; Seiichiro Shiratori, Serizawa Keisuke no Shizuoka Jidai, (Shizuoka, 2016), 72.

36 Some objects in his collection were obtained through dealers in Japan in around the 1970s.

37 Muneyoshi Yanagi, Watashi no Nengan, (Tokyo, 1942), 117-118.

38 Shoji Hamada, Mujinzo, (Tokyo: Asahi Shimbum, 1974), 148.

39 Hanako Shimada, "Hamada Shoji to Umehara Ryuzaburo" in Mashiko Museum of Ceramic Art ed., Hamada ga deatta Miwaku no Kindai, (Mashiko, 2012), 94.

${ }^{40}$ Hamada, Mujinzo, 161.
} 
selected by my eyes to nourish my mind."41 Thus it is clear that Hamada collected these pieces to gain inspiration for his creative output.
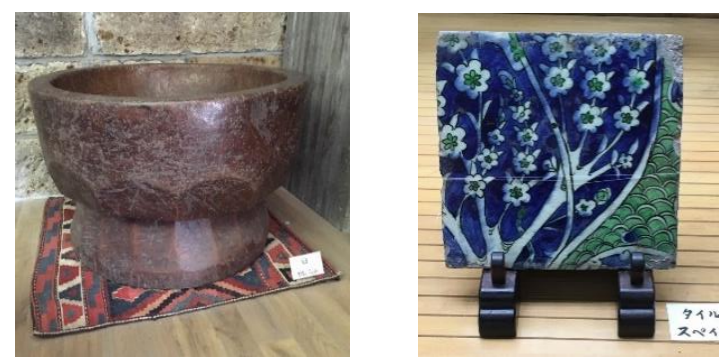

Fig. 10 Examples of tribal textile and Islamic pottery in Shoji Hamada Memorial Mashiko Sankokan Museum Photograph taken by the author

Kichinosuke Tonomura (1898-1993) was a textile artist and played an active role in the Mingei Movement established by Yanagi. Tonomura became the director of the Kurashiki Museum of Folkcraft in 1948. Tonomura tried to disseminate Yanagi's thought and spirit through writing, collecting, and putting on exhibitions. In 1957, he traveled to 14 countries in Europe and collected a wide range of artifacts. His 1962 book, Seiou no Mingei (Handicraft of Western Europe) shows images of Turkish and Persian kilims. A decade later in 1972, he published Sekai no Mingei (Handicraft of the World) with Serizawa and Hamada and introduced a variety of items including tent bands made by Iranian nomads. Also, under his directorship, a second volume of the catalogue of the Kurashiki Museum of Folkcraft was published, which contains images of kilims and bags made by nomads (Fig. 11). ${ }^{42}$
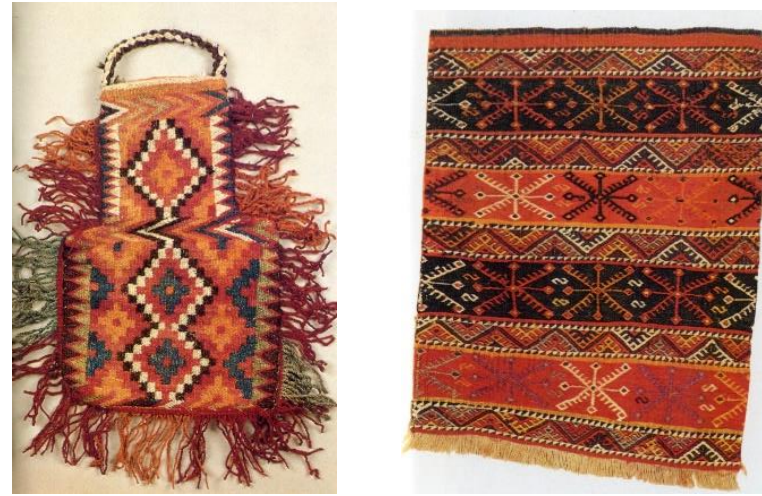

Fig. 11 Tribal textiles collected by Kichinosuke Tonomura After Tonomura, Kurashiki Mingeikan Zuroku, pl. 19 and pl. 27

\section{Conclusion}

\footnotetext{
41 Hamada, Mujinzo, Introduction.

42 Kichinosuke Tonomura, Kurashiki Mingeikan Zuroku, vol. 2, (Okayama, 1981), pls, 11-13, 18-19, 26-29, 4547.
} 
In Europe, Oriental carpets including tribal carpets were used as interior decoration from the late nineteenth century. American collectors also found beauty in Oriental carpets. George Hewitt Myers (1875-1957), a founder of the Textile Museum in Washington D.C., stated that carpets contained "some of the most fundamental forms of human expression" and held an appeal that self-conscious art did not. Myers thought that the value of self-conscious art forms such as painting was based on the reputation of the artist, whereas the value of objects made by anonymous individuals was measured by the quality of the objects themselves. ${ }^{43}$ This view is in common with the thought of Muneyoshi Yanagi.

In the early twentieth century, Yanagi and other privileged scholars, businessmen, and artists had the opportunity to visit Europe and America and learn about the tradition of using carpet as an interior furnishing. Some of them brought carpets back to Japan. For Yanagi, carpet was one of the idealized handicrafts that realized the principles of art and nature that he espoused. As demonstrated in this paper, his attitude toward carpet was similar to that of William Morris who also highly valued Oriental carpets and gained inspiration from them. Yanagi's friends and followers in the Mingei Movement such as Keisuke Serizawa, Shoji Hamada, and Kichinosuke Tonomura also collected carpets as idealized handicrafts and as a source of creative impetus.

Yanagi wished to "make the world more beautiful" and he wanted to show that "it was impossible to understand beauty without reference to daily life" ${ }^{44}$ while Morris stated: "Have nothing in your houses which you do not know to be useful or believe to be beautiful". ${ }^{45}$ It is thought-provoking that both of them valued and used Oriental carpet in their daily life. Thus it could be said that Oriental carpet is the object that epitomizes the thought of both Yanagi and Morris on the idealized beauty to be found in handicrafts.

Bibliography

Asahi Beer Oyamazaki Villa Museum of Art アサヒビール大山崎山荘美術館. Asahi Beer Oyamazaki Sanso Bijutsukan Guidebook『アサヒビール大山崎山荘美術館ガイド ブック』(Guidebook of the Asahi Beer Oyamazaki Villa Museum of Art). Kyoto, 2012.

Cassel-Pihl, Eva Helena. The Hallwyl Collection of Oriental Carpets and Textiles. Stockholm: Hallwylska Museet, 2003.

Cole, G.D.H. ed. William Morris: Stories in Prose, Stories in Verse, Shorter Poems, Lectures

43 Thomas J. Farnham, "In Pursuit of High Standards," Hali 184 (2015), 56-57.

${ }^{44}$ Muneyoshi Yanagi, Watashi no Nengan, (Tokyo, 1942), 20-21.

${ }^{45}$ G.D.H. Cole, ed., William Morris: Stories in Prose, Stories in Verse, Shorter Poems, Lectures and Essays, (London: The Nonesuch Press, 1948), 562. 
and Essays. London: The Nonesuch Press, 1948.

Denny, Walter B. and Farnham, Thomas J. The Carpet and the Connoisseur: The James F. Ballard Collection of Oriental Rugs. Saint Louis: Saint Louis Art Museum, 2016.

Edinburgh City Museum and Art Galleries ed. Eastern Rugs from Lauriston. Edinburgh, 1986.

Farnham, Thomas J. "In Pursuit of High Standards" Hali (184) 2015, 52-63.

Hamada, Shoji 濱田庄司. Mujinzo『無尽蔵』(Unlimited). Tokyo: Asahi Shimbun, 1974.

Hawley, Walter A. Oriental Rugs: Antique and Modern. New York: John Lane Company, 1913.

Henderson, Philip ed. The Letters of William Morris to His Family and Friends. London: Longmans, 1950.

Henderson, Philip. William Morris: His Life, Work and Friends. London: Thames and Hudson, 1967.

Hosokawa, Morihiro 細川護熙 ed. Bi ni ikita Hosokawa Moritatsu no Me『美に生きた細 川護立の眼』(Eyes of Moritatsu Hosokawa Who Lived on Beauty). Tokyo: Kyuryudo, 2010.

Jacobson, Charles W. Facts about Oriental Rugs. New York: The Du Bois Press, 1931.

Kamada, Yumiko. Flowers on Floats: The Production, Circulation, and Reception of Early Modern Indian Carpets. Ph.D. Dissertation, Institute of Fine Arts, New York University, 2011.

Kamada, Yumiko 鎌田由美子. Jutan ga musubu Sekai: Kyoto Gion Matsuri Indo Jutan

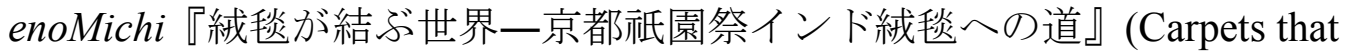
Connect the World: Indian Carpets and their Journey toward the Kyoto Gion Festival). Nagoya: The University of Nagoya Press, 2016.

Kamada, Yumiko 鎌田由美子. “Yanagi Muneyoshi no Shizenkan to Jutan「柳宗悦の自然 観と絨毯」(Yanagi Muneyoshi's view on nature and carpet)” in Kanzaki, Tadaaki and Nomoto, Shin eds., 『自然を前にした人間の哲学』Shizen o mae ni shita Ningen no Tetsugaku (Philosophy of human being that faces nature). Tokyo: Keio University Press, Tokyo, 2020, 241-267.

Kanemitsu, Akira 金光章. Mingei to Kurashiki『民藝とくらしき』(Mingei and Kurashiki). Okayama: Kibito Shuppan, 2002.

Keimeikai 啓明会. Keimeikai Soritsu Junen Kinen Tenrankai Zuroku『啓明会創立十年記 念展覧会図録』(Catalogue of an Exhibition for the Tenth Anniversary of the Keimeikai). Tokyo: Kogeisha, 1928.

Kendrick, A.F. and Tattersall, C.E.C. Hand-Woven Carpets: Oriental and European. London: Benn Brothers, 1922.

Masuyama, Shinpei 増山新平. Shinjidai no Shitsunai Setsubi Kozo Zukai『新時代の室内設 備構造図解』(Illustrated Work on Interior Equipment in a New Age). Tokyo: Taiyosha, 1938.

Matsuoka, Yuzuru 松岡譲. Soseki Shashinjo『漱石写真帖』(The Picture Album of Soseki). Tokyo: Daiichi Shobo, 1928.

Mie Prefectural Museum 三重県立美術館. Yanagi Muneyoshi Ten『柳宗悦展』(Exhibition on Yanagi Muneyoshi). Tsu: Mie Prefectural Museum, 1997.

Mizuo, Hiroshi 水尾比呂志 ed. Yanagi Muneyoshi Mingei Kiko『柳宗悦 民藝紀行』 (Yanagi Muneyoshi’s Mingei Journey). Tokyo: Iwanami Shoten, 1995.

Moriya, Nobuo 森谷延雄. Korekara no Shitsunai Soshoku『これからの室内装飾』 (Interior Decoration From Now On). Tokyo: Taiyodo Shoten, 1927.

Morris, Barbara. "William Morris and the South Kensington Museum" Victorian Poetry 13 
(1975), 159-175.

Morris, May. William Morris: Artist, Writer, Socialist. Vol. 1, New York: Russell and Russell, 1966.

Morris, William. The Collected Works of William Morris. Vol. 22, London: Longmans, 1914. Morris, William. The Collected Works of William Morris. Vol. 23, London: Longmans, 1915. Morris, William. The Art of the People. Worcestershire: Read Books Ltd, 2012.

Mumford, John Kimberly. Oriental Rugs. New York: Charles Scribner's Sons, 1929.

Nihon Mingeikan 日本民藝館 ed. Yanagi Muneyoshi Zenshu『柳宗悦全集』(The

Complete Works of Yanagi Muneyoshi). Vol. 10, Tokyo: Chikuma Shobo, 1982.

Nihon Mingeikan 日本民藝館 ed. Yanagi Muneyoshi Collection『柳宗悦コレクション』

(The Collection of Yanagi Muneyoshi). Vol. 2, Tokyo: Chikuma Shobo, 2011.

Parry, Linda. William Morris Textiles. New York: The Viking Press, 1983.

Shimada, Hanako 嶋田華子. “Hamada Shoji to Umehara Ryuzaburo「濱田庄司と梅原龍

三郎」(Shoji Hamada and Ryuzaburo Umehara)" in Mashiko Museum of Ceramic Art 益子陶芸美術館 ed. Hamada ga deatta Miwaku no Kindai『濱田が出会つた鬼惑の 近代』(Hamada Shoji’s Perspective on Modernity), Mashiko: Mashiko Museum of Ceramic Art, 2012, 91-94.

Shimonoseki City Art Museum下関市立美術館 Kawamura Kojiro to Bi no

Sekai 『河村幸次郎之美の世界』(Kojiro Kawamura and the World of Beauty).

Shimonoseki: Shimonoseki City Art Museum, 2013.

Shiratori, Seiichiro 白鳥誠一郎. Serizawa Keisuke no Shizuoka Jidai『芹沢銈介の静岡時

代』(Keisuke Serizawa’s Time in Shizuoka). Shizuoka: Shizuoka Shimbun, 2016.

Thompson, Jon. Timbuktu to Tibet. New York: Hajji Baba, 2008.

Thompson, Paul Richard. The Work of William Morris. New York: The Viking Press, 1967.

Tonomura, Kichinosuke 外村吉之介. Seiou no Mingei 『四欧の民芸』(Handicraft of Western

Europe). Tokyo: Toho Shuppan, 1962.

Tonomura, Kichinosuke外村吉之介, Serizawa, Keisuke芹沢銈介and Hamada, Shoji濱田庄司

Sekai no Mingei 『世界の民芸』(Handicraft of the World). Tokyo: Asahi Shimbun, 1972.

Tonomura, Kichinosuke 外村吉之介. Kurashiki Mingeikan Zuroku『倉敷民藝館闵録 (Catalogue

of Kurashiki Museum of Folkcraft ). Vol. 2. Okayama: Kurashiki Mingeikan, 1981.

Yanagi, Munemoto 柳宗立 Cappadocia no Natsu『カッパドキヤの夏』(A Summer in

Cappadocia). Tokyo: Chuokoronsha, 1988.

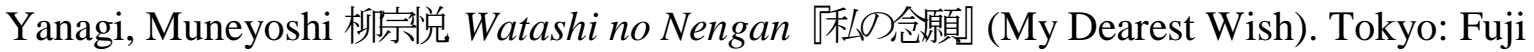

Shobo, 1942.

Yanagi, Muneyoshi 柳宗悦 Yanagi Muneyoshi Senshu 柳宗悦巽集』(Selected Works of

Yanagi Muneyoshi). Vol. 3. Tokyo: Shunjusha, 1954.

Zuanka Kyokai 図案家協会. Chua Geijutsu Shusei 『中亜芸術魅成』(Collection of the Arts of

Central Asia). Kyoto: Unsodo, 1924. 